\title{
ОСОБЛИВОСТІ ЕНЕРГОЗАБЕЗПЕЧЕННЯ СТІНКИ ТОНКОЇ КИШКИ ПРИ ХРОНІЧНОМУ ЕНТЕРОКОЛІТІ НА ФОНІ СТРЕПТОЗОТОЦИНІНДУКОВАНОГО ДІАБЕТУ В ЩУРІВ
}

\begin{abstract}
Резюме. Незважаючи на різноманітність патогенезу досліджуваних патологій, розвиток хронічного запалення через порушення кишкового метаболізму, на думку деяких авторів, є вирішальним при хронічному ентероколіті й цукровому діабеті.

Мета дослідження - з'ясувати стан енергозабезпечення стінки тонкої кишки при хронічному ентероколіті на фроні стрептозотоцинового діабету.

Матеріали і методи. Дослідження проведено на 48 білих нелінійних самцях-щурах з дотриманням принципів Європейської конвенції про захист хребетних тварин, що використовуються для дослідних та наукових цілей (Страсбург, 1986). Цукровий діабет (СТД) моделювали шляхом однократного внутрішньочеревного введення тваринам віком 2 місяці стрептозотоцину (Sigma Aldrich, США, в дозі 60 мг/кг маси тіла). Хронічний ентероколіт (ХЕК) було відтворено шляхом вільного доступу тварин до 1,0 \% розчину карагінану в питній воді протягом 1 місяця. Активність сукцинатдегідрогенази, цитохромоксидази і трансаміназ проводили за стандартними методиками.

Результати досліджень та їх обговорення. Встановлено достовірне зростання активності амінотранссрераз у гомогенаті тонкої кишки при СТД, тоді як при ХЕК статистично значимо підвищувалася лише активність АлАТ. Слід зазначити, що при ХЕК на фоні СТД встановлено найвищі показники активності амінотрансфераз. Встановлено, що за умови змодельованого ХЕК на тлі СТД у мітохондріях м'язового шару стінки тонкої кишки відмічається зниження активності СДГ на $44,78 \%$ і ЦХО - на 33,18 \% проти даних контролю $(\mathrm{p}<0,01)$. При цьому в тварин із ХЕК на фоні СТД виявляли максимальний енергодесріцит, який був статистично значним від результатів досліджуваних показників при ХЕК (СДГ на 14,50 \% і ЦХО - на 8,40 \%) і СТД (СДГ на 29,59 \% і ЦХО - на 19,21 \%). Отримані зміни активності СДГ і ЦХО свідчать про пригнічення фрункції мітохондрій в ентероцитах при всіх досліджуваних патологіях, що може бути однією з причин зростання активності амінотранссераз унаслідок ушкодження клітин.

Висновки. За умови хронічного ентероколіту на тлі стрептозотоцинового діабету інтенсифрікація процесів окиснювальної деструкції супроводжується змінами ензиматичної активності показників енергозабезпечення (зниження активності сукцинатдегідрогенази - на 44,8 \% і цитохромоксидази на 33,2 \%), що веде до деструктивного ушкодження клітин тонкої кишки (підвищення активності АлАТ на 32,02 \% і АсАТ - на 20,47 \%), p<0,01.
\end{abstract}

Ключові слова: хронічний ентероколіт; стрептозотоциновий діабет; енергозабезпечення; амінотранссерази; експеримент.

ВСТУП Патобіохімічні зміни в клітинах кишкового епітелію є одним із суттєвих механізмів прогресування захворювання з розвитком поліорганної недостатності. У даний час $є$ значна кількість літературних джерел, в яких показано, що патологічні зміни у тонкій кишці займають важливе місце в симптомокомплексі ушкоджень при експериментальному цукровому діабеті (ЦД) [1-3]. Протягом останніх десятиліть поширеність ЦД набула епідемічних значень, при цьому, як зазначає Wenjun Fan [4], близько половини всіх людей з діабетом не знають про їх захворювання, що зумовлює високу частоту розвитку ускладнень [5].

Дослідники виявили, що цукровий діабет 1 типу є одним із трьох найпоширеніших супутніх захворювань пацієнтів з хронічним ентероколітом (ХЕК) [6]. Як ХЕК, так і ЦД мають подібні ускладнення, включаючи нейропатію, венозний тромбоз, остеопороз та багато інших. Незважаючи на різноманітність патогенезу досліджуваних патологій, розвиток хронічного запалення через порушення кишкового метаболізму, на думку деяких авторів, є вирішальним при ХЕК і ЦД [7]. Попередні результати досліджень вказують на те, що у розвитку хронічного ентероколіту на фроні стрептозотоцинового діабету беруть участь як вільнорадикальні процеси, так і запальний процес, проте сильніший зв'язок встановлено з активними формами оксигену [8]. Дані, отримані нами й іншими науковцями, дають підстави шукати зв'язки між досліджуваними патологіями.

Метою дослідження було з'ясувати стан енергозабезпечення стінки тонкої кишки при хронічному ентероколіті на фроні стрептозотоцинового діабету.

МАТЕРІАЛИ І МЕТОДИ Дослідження проведено на 48 білих нелінійних самцях-щурах, яких утримували на стандартному раціоні віварію Тернопільського державного медичного університету імені І. Я. Горбачевського. Під час роботи дотримувалися принципів Європейської конвенції про захист хребетних тварин, що використовуються для дослідних та інших наукових цілей (Страсбург, 1986). Піддослідних щурів поділили на чотири групи: перша - контроль (інтактні тварини), друга - тварини 3 цукровим діабетом, третя - тварини з хронічним ентероколітом, четверта - тварини з цукровим діабетом і хронічним ентероколітом. Цукровий діабет (СТД) моделювали шляхом однократного внутрішньочеревного введення тваринам віком 2 місяці стрептозотоцину (Sigma Aldrich, США, в дозі 60 мг/кг маси тіла) [9]. Безпосередньо перед введенням стрептозотоцин розчиняли в 0,1 молярному цитратному буфері (pH 4,5); контрольній групі вводили відповідну кількість цитратного буферу. В експерименті використовували тварин з рівнем глюкози не нижче 10,8 ммоль/л через 2 тижні після введення стрептозотоцину. Хронічний ентероколіт було відтворено шляхом вільного доступу тварин до 1,0 \% розчину карагінану в питній воді протягом 1 місяця [10, 11].

За методикою, розробленою нами, проводили виділення мітохондрій м'язового шару стінки тонкої кишки. Під нембуталовим наркозом (30 мг/кг) з черевної порожнини тварин вилучали тонку кишку, яку негайно промивали й очищали від вмісту крижаним орізіологічним розчином, потім поміщали в охолоджене до $0^{\circ} \mathrm{C}$ середовище виділення, яке складалося з 120 мМ манітолу, 70 мМ сахарози, 50 мМ Тріс-НС, 5мМ ЕДТА, 2 \% ліофілізованого сироваткового альбуміну бика (фірма "Sigma", $\mathrm{pH}=7,4)$. Усі наступні маніпуляції виконували при температурі 0-2 ${ }^{\circ} \mathrm{C}$ з використанням попередньо охолодженого посуду та інструментів. Ділянку тонкої кишки поздо- 
вжньо розкривали гострим краєм предметного скла, видаляли слизовий і серозний шари, після чого матеріал промивали середовищем виділення. Подрібнену тканину гомогенізували при додаванні 1 мл середовища виділення на 1 г тканини в скляному гомогенізаторі ПоттераЕльвегейма з тесрлоновим товкачиком із 4-5 вертикальними ходами пестика. Гомогенат центрифугували при $600 \mathrm{~g}$ і $4{ }^{\circ} \mathrm{C} 10$ хв із метою осадження ядер і зруйнованих клітин. Отриманий супернатант центрифугували при $12000 \mathrm{~g}$ і $4{ }^{\circ} \mathrm{C}$ протягом 10 хв. Супернатант видаляли, осад ресуспендували в 30 мл середовища виділення і суспензію центриоругували при $12000 \mathrm{~g}$ і $4{ }^{\circ} \mathrm{C}$ протягом 10 хв. Супернатант видаляли, осад суспендували в середовищі виділення до концентрації 30-40 мг білка на мл.

Сукцинатдегідрогеназну (СЦД, КФ 1.3.99.1) активність визначали за її здатністю відновлювати фероціанід калію до фрероціаніду сукцинату, цитохромоксидазну активність (ЦХО, КФ 1.9.3.1) - за її здатністю окиснювати диметилпара-сренілендіамін і 6-насртол з утворенням індофенолового синього $[8,12]$.

Активність аланін- та аспартатамінотрансфераз (АлАТ, КФ.2.6.1.2; АсАТ, КФ.2.6.1.1) визначали у супернатанті гомогенату стінки кишки спектрофотометрично [13].

Отримані дані піддавали статистичній обробці $[14,15]$. Для перевірки на відповідність вибірок даних нормальному закону розподілу було застосовано розрахунок критерію Шапіро-Уілка. У зв'язку з відсутністю відповідності даних нормальному розподілу на рівні значимості p<0,05 обчислювали средньовибіркові характеристики. Рівень статистичної значущості відмінностей вибірок оцінювали за допомогою непараметричного критерію Манна-Уїтні. Відмінності вважали статистично значущими при досягнутому рівні $\mathrm{p}<0,05$.

РЕЗУЛЬТАТИ ДОСЛІДЖЕНЬ ТА ЇХ ОБГОВОРЕННЯ Встановлено достовірне зростання активності амінотрансорераз у гомогенаті тонкої кишки при СТД, тоді як при ХЕК статистично значимо підвищувалася лише активність АлАТ (рис.). Це зумовлено тим, що навіть при незначних ушкодженнях мембрани ентероцитів паренхімні фрерменти легко виділяються і реєструється їх підвищена активність у супернатанті м'язового шару стінки тонкої кишки. Інший досліджуваний ензим - АсАТ пере- важно міститься у мітохондріях ентероцитів, тому підвищена його активність реєструється при глибших структурних ушкодженнях біологічних мембран [16]. Слід зазначити, що при ХЕК на фоні СТД встановлено найвищі досліджувані показники: активність АлАТ перевищувала на 32,02 \% показники контролю і на 17,8 \% дані при СТД, активність АсАТ, відповідно, на 20,47 і 14,55 \% (p<0,05).

Активація процесів пероксидного окиснення ліпідів [8] може призводити до порушення проникності клітинних мембран, гальмування окисного фросфорилування у мітохондріях, пригнічення синтезу ДНК та поділу клітин, що сприяє розвитку хронічного рецидивного запалення і деструктивного ушкодження слизової оболонки тонкої кишки $[17,18]$. На даний час малодослідженим залишається питання реакції-відповіді мітохондрій на негативні впливи різної інтенсивності та природи, адже механізм адаптації організму залежить від стану енергетичних процесів у клітині [19].

Отримані зміни активності СДг і ЦХО свідчать про пригнічення фрункції мітохондрій в ентероцитах при всіх досліджуваних патологіях, що може бути однією з причин зростання активності амінотрансорераз унаслідок ушкодження клітин. Встановлено, що за умови змодельованого ХЕК на тлі СТД у мітохондріях м'язового шару стінки тонкої кишки відмічається зниження активності СДГ на $44,78 \%$ і ЦХО - на 33,18 \%, проти даних контролю $(p<0,01)$. При цьому в тварин із ХЕК на фроні СТД виявляли максимальний енергодефіцит, який був статистично значним від результатів досліджуваних показників при ХЕК (СДГ на 14,50 \% і ЦХО - на 8,40 \%) і СТД (СДГ на $29,59 \%$ і ЦХО - на 19,21 \%) (табл.).

Сповільнення процесів клітинного дихання мітохондрій, порушення енергетичного обміну клітини внаслідок пригнічення фоссрорилування, інактивація дії інсуліну можуть бути спричинені ендотоксикозом при хронічному ентероколіті на фроні стрептозотоцинового діабету, метаболічним результатом якого у щурів є посилення клітинної деструкції, що ми підтверджували зростанням рівня нуклеїнових кислот у крові тварин.

За умови гіперглікемії при цукровому діабеті посилена генерація кисневих радикалів спричинює зміни молекулярних структур мітохондрій, які виявляються в інтенсифрікації процесів окиснювальної деструкції та орракцій-

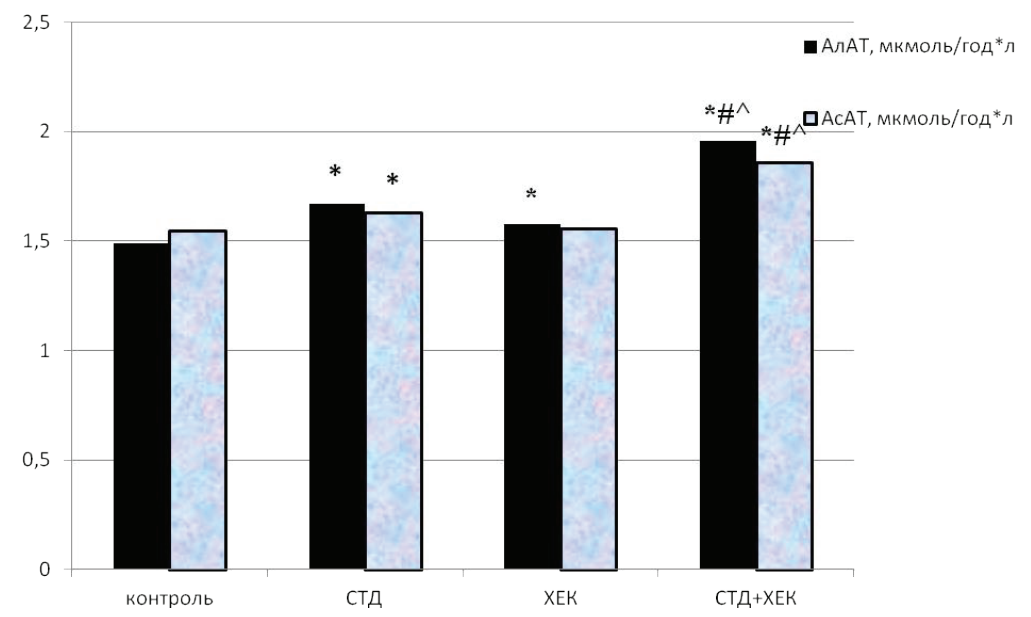

Рис. Зміни активності амінотрансорераз при експериментальних хронічному ентероколіті, цукровому діабеті та їх поєднанні.

Примітки. Тут і в таблиці: * - відмінність між контролем і дослідною групою статистично значима (p<0,05-0,001); ^ - показник достовірності між другою і четвертою групами; \#-показник достовірності між третьою і четвертою групами. 
Таблиця. Динаміка активності супероксиддисмутази і цитохромоксидази в мітохондріях м'язового шару стінки тонкої кишки щурів при хронічному ентероколіті на фоні стрептозотоцинового діабету

\begin{tabular}{|l|c|c|}
\hline \multicolumn{1}{|c|}{ Група спостереження } & $\begin{array}{c}\text { Активність супероксиддисмутази, нМ } \\
\text { сукцинату/мг протеїну в хв }\end{array}$ & $\begin{array}{c}\text { Активність цитохромоксидази, нМ диметил- } \\
\text { п-сренілендіаміну/мг протеїну в хв }\end{array}$ \\
\hline Контроль & $4,98 \pm 0,18$ & $4,48 \pm 0,13$ \\
\hline СТД & $3,22 \pm 0,02^{*}$ & $3,26 \pm 0,03^{\star}$ \\
\hline ХЕК & $3,91 \pm 0,11^{*}$ & $3,70 \pm 0,04^{\star}$ \\
\hline СТД+ХЕК & $2,75 \pm 0,12^{\star} \#^{\wedge}$ & $2,99 \pm 0,04^{\star} \#^{\wedge}$ \\
\hline
\end{tabular}

ному перерозподілі продуктів мітохондріальної трансляції, що супроводжується змінами ензиматичної активності сукцинатдегідрогенази та цитохромоксидази. При поєднанні хронічного ентероколіту й цукрового діабету в щурів дихальний ланцюг мітохондрій стає потужним продуцентом активних форм кисню, які, ймовірно, стимулюють запуск порушень структурно-фрункціональної організації хроматину клітин ентероцитів.

\section{СПИСОК ЛІТЕРАТУРИ}

1. Малиновская Н. А. Поражения пищеварительного тракта при сахарном диабете / Н. А. Малиновская // Бук. мед. вісник. - 2010. - T. 14, № 1 (53). - С. 168-172.

2. Циммерман Я. С. Сахарный диабет и функциональноструктурные изменения в гастродуоденальной зоне : клиникоэпидемиологическое исследование / Я. С. Циммерман, М. Р. Зинатуллин // Тер. архив. - 2011. - Т. 83, № 2. - С. 71-75.

3. Gastrointestinal tract symptoms among persons with diabetes mellitus in the community / D. Maleki, G. R. Locke, M. Camilleri [et al.] // Arch. Intern. Med. - 2008. - № 160. - P. 2808-2016. Available at: http://archinte.ama-assn.org/cgi/content/ full/160/18/2808. Accessed August 7, 2008.

4. Wenjun F. Epidemiology in diabetes mellitus and cardiovascular disease / F. Wenjun // Cardiovascular Endocrinology. - 2017. Vol 6, Issue 1 - P. 8-16.

5. Prevalence and risk factors of diabetes in a large communitybased study in North India: results from a STEPS survey in Punjab, India / Jaya Prasad Tripathy, J. S. Thakur, G. Jeet [et al.] // Diabetol Metab. Syndr. - 2017. - № 9. - P. 8

6. Glucose intolerance and diabetes mellitus in ulcerative colitis: Pathogenetic and therapeutic implications / G. Maconi, F. Furfaro, R. Sciurti [et al.] // J Gastroenterol. - 2014. - № 20. - P. 3507-3515.

7. Maloy K. J. Intestinal homeostasis and its breakdown in inflammatory bowel disease / K. J. Maloy, F. Powrie // Nature. - 2011. - № 5. - P. 7.

8. Порушення енергозабезпечення тканини печінки як один із механізмів аліментарного ожиріння / О. П. Мялюк, І. М. Кліщ, В. В. Заєць, М. М. Марущак // Наукові доповіді НУБіп України. - 2016. - № 58 (лютий). - Режим доступу: http://nd.nubip.edu. ua/2016_1/5.pdf.

9. Indomethacin inhibits thymic involution in mice with streptozotocininduced diabetes / V. L. Ordodi, V. Paunescu, M. Ionac [et al.] // Artificial organs. - 2008. - Vol. 32 (1). - P. 66-70.
ВИсновки За умови хронічного ентероколіту на тлі стрептозотоцинового діабету інтенсифікація процесів окиснювальної деструкції супроводжується змінами ензиматичної активності показників енергозабезпечення (зниження активності сукцинатдегідрогенази на 44,8 \% і цитохромоксидази - на 33,2 \%), що веде до деструктивного ушкодження клітин тонкої кишки (підвищення активності АлАТ на 32,02 \% і АсАТ - на 20,47\%), p<0,01.

10. Moyana T. N. Carrageenan-induced intestinal injury in the rat--a model for inflammatory bowel disease / T. N. Moyana, J. M. Lalonde // Ann. Clin. Lab. Sci. - 1990. - Vol. 20 (6). - P. 420-426.

11. Пат. 97322. Україна, МПК: G09B 23/28. Спосіб моделювання хронічного гастроентероколіту / Г. І. Губіна-Вакулик, Н. Г. Колоусова, Т. О. Іваненко, Т. В. Горбач, В.О.Коробчанський ; власник Харківський нац. мед. ун-т. - № а201014510 ; заявл. 06.12.2010 ; опублік. 25.01.2012, Бюл. № 2. - 4 c.

12. Посібник з експериментально-клінічних досліджень в біології та медицині ; під ред. І. П. Кайдашева, О. В. Катрушова, В. М. Соколенко, О. І. Цебржинського. - Полтава, 1996. - 271 с.

13. Меньшиков В. В. Лабораторные методы исследования в клинике / В. В. Меньшиков. - М. : Медицина, 1987. - 368 с.

14. Гланц С. Медико-биологическая статистика : пер. $з$ англ. / С. Гланц. - М. : Практика, 1999. - 459 с.

15. Реброва О. Ю. Статистический анализ медицинских данных. Применение пакета прикладных программ STATISTICA / О. Ю. Реброва. - М. : МедиаСфера, 2002. - 312 с.

16. Vaginal gel formulation based on theaflavin derivatives as a microbicide to prevent HIV sexual transmission, AIDS / J. Yang, L. Li, H. Jin [et al.] // Res. Hum. Retroviruses. - 2012. - № 28 P. 1498-1508.

17. Fomenko I. The role of lipid peroxidation processes in the formation of ulcerogenic lesions of colonic mucosa under conditions of different stress models / I. Fomenko // Visnyk Probl. Biol. and Med. - 2015. - № 1(122). - P. 223-226.

18. Голота Ю. Окисно-антиоксидантна рівновага в слизовій оболонці товстої кишки щурів у різні терміни після введення цестриаксону / Ю. Голота, А. Базан, Г. Толстанова // Вісник Київського національного університету імені Тараса Шевченка. - 2017. - C. 25-33.

19. Fisette A. Obesity-inducing diet promotes acylation stimulating protein resistance / A. Fisette, M. Lapointe, K. Cianflone // Biochem. Biophys. Res. Commun. - 2013. - Vol. 437 - № 3. - P. 403-407. 

WITH STREPTOZOTOCIN-INDUCED DIABETES IN RATS

Summary. Despite the diversity of the studied pathologies pathogenesis, the development of chronic inflammation due to a violation of intestinal metabolism, according to some authors, is crucial in chronic enterocolitis and diabetes mellitus.

The aim of the study - to find out the state of energy supply in the wall of the small intestine in chronic enterocolitis combined with streptozotocin diabetes.

Materials and Metods. The study was conducted on 48 white non-linear male rats in accordance with the principles of the European Convention for the Protection of Laboratories. Diabetes mellitus (DM) was modeled by a single intraperitoneal administration of streptozotocin to animals aged 2 months, (Sigma Aldrich, USA, at a dose of $60 \mathrm{mg} / \mathrm{kg}$ of body weight). Chronic enterocolitis (CEC) was induced by a free access of animals to $1.0 \%$ solution of carrageenan in drinking water for 1 month. The activity of succinate dehydrogenase (SD), cytochrome oxidase (CO) and transaminases was performed according to standard methods.

Results and Discussion. A significant increasing in the activity of aminotransferases in the small intestine homogenate at DM was established, whereas in the case of CEC only ALaT activity was statistically significantly increased. It should be noted that at CEC combined with STD, the highest rates of aminotransferase activity are established. It was established that under the condition of simulated CEC on the background of STD in the mitochondria of the muscular layer of the wall of the small intestine there is a decrease in the activity of SD at $44.78 \%$ and $\mathrm{CO}-33.18 \%$, against the data of control $(p<0.01)$. At the same time, the animals with CEC on the background of DM showed the maximum energy deficit, which was statistically significantly higher than the results of the studied indicators for CEC (SD at $14.50 \%$ and CO - 8.40 \%) and DM (SD at $29.59 \%$ and CO - on 19.21\%). The received changes in the activity of SD and CO indicate the inhibition of the mitochondria function in enterocytes in all studied pathologies, which may be one of the causes of increased activity of aminotransferases due to cell damage.

Conclusions. In case of chronic enterocolitis combined with streptozotocin diabetes, the intensification of oxidative destruction processes is accompanied by changes in the enzymatic activity of energy supply indices (reduction of the activity of succinate dehydrogenase by $44.8 \%$ and cytochrome oxidase by $33.2 \%$ ), which leads to destructive damage of the small intestine cells (increased activity of AIAT by $32.02 \%$ and AsAT by $20.47 \%)$, p $<0.01$.

Key words: chronic entrocolitis; streptozotocin diabetes; energy supply; aminotransferases; experiment.

ОМ. И. Марущак, Н. В. Лиснянская, Г. Г. Габор

ГВУз “Тернопольский государственный медицинский университет имени И. Я. Горбачевского”

\section{ОСОБЕННОСТИ ЭНЕРГООБЕСПЕЧЕНИЯ СТЕНКИ ТОНКОЙ КИШКИ ПРИ ХРОНИЧЕСКИМ ЭНТЕРОКОЛИТЕ НА ФОНЕ СТРЕПТОЗОТОЦИНИНДУЦИРОВАННОГО ДИАБЕТА У КРЫС}

Резюме. Несмотря на разнообразие патогенеза исследуемых патологий, развитие хронического воспаления из-за нарушения кишечного метаболизма, по мнению некоторых авторов, является решающим при хроническом энтероколите и сахарном диабете.

Цель исследования - выяснить состояние энергообеспечения стенки тонкой кишки при хроническом энтероколите на сроне стрептозотоцинового диабета.

Материалы и методы. Исследование проведено на 48 белых нелинейных самцах-крысах с соблюдением принципов Европейской конвенции по защите лабораторных животных. Сахарный диабет (СТД) моделировали путем однократного внутрибрюшного введения животным в возрасте 2 месяца, стрептозотоцина (Sigma Aldrich, США, в дозе 60 мг/кг массы тела). Хронический энтероколит (ХЭК) был воссоздан путем свободного доступа животных к 1,0 \% раствору каррагинана в воде в течение 1 месяца. Активность сукцинатдегидрогеназы, цитохромоксидазы и трансаминаз проводили по стандартным методикам.

Результаты исследований и их обсуждение. Установлено достоверное повышение активности аминотранссераз в гомогенате тонкой кишки при СТД, тогда как при ХЭК статистически значимо повышалась только активность АлАТ. Следует отметить, что при ХЭК на фоне СТД установлены самые высокие показатели активности аминотранссераз. Установлено, что при смоделированном ХЭК на фроне СТД в митохондриях мышечного слоя стенки тонкой кишки отмечается снижение активности СДГ на 44,78 \% и ЦХО - на 33,18 \% против данных контроля (р<0,01). При этом у животных с ХЭК на фроне СТД проявился максимальный энергодесицит, который был статистически значимым относительно результатов исследуемых показателей при ХЭК (СДГ на 14,50 \% и ЦХО - на 8,40 \%) и СТД (СДГ на 29,59 \% и ЦХО - на 19,21 \%). Полученные изменения активности СДГ и ЦХО свидетельствуют об угнетении фрункции митохондрий в энтероцитах при всех исследуемых патологиях, что может быть одной из причин роста активности аминотрансфераз в результате повреждения клеток.

Выводы. При хроническом энтероколите на фроне стрептозотоцинового диабета интенсисрикация процессов окислительной деструкции сопровождается изменениями энзиматической активности показателей энергообеспечения (снижение активности сукцинатдегидрогеназы на 44,8 \% и цитохромоксидазы - на 33,2 \%), что ведет к деструктивному повреждению клеток тонкой кишки (повышение активности АлАТ на 32,02 \% и АсАТ - на 20,47 \%), р<0,01.

Ключевые слова: хронический энтероколит; стрептозотоциновый диабет; энергообеспечение; аминотрансореразы; эксперимент. 